\title{
ASPARAGINASE II-GFP FUSION AS A TOOL FOR STUDYING THE SECRETION OF THE ENZYME UNDER NITROGEN STARVATION
}

\author{
Adriana Sotero-Martins ${ }^{1,2}$; Elba Pinto da Silva Bon ${ }^{1 *}$; Elvira Carvajal ${ }^{3}$ \\ ${ }^{1}$ Universidade Federal do Rio de Janeiro, Rio de Janeiro, RJ, Brasil. ${ }^{2}$ Centro de Pesquisa Leônidas e Maria Deane, \\ Fundação Oswaldo Cruz, Manaus, AM, Brasil. ${ }^{3}$ Universidade do Estado do Rio de Janeiro, Rio de Janeiro, RJ, Brasil. \\ This paper corresponds to an "extended abstract" selected for oral presentation in the $22^{\text {nd }}$ Brazilian Congress of Microbiology, \\ held in Florianópolis, SC, Brazil, in November 17-20, 2003
}

\begin{abstract}
Production of asparaginase II of Saccharomyces cerevisiae is regulated by nitrogen and can be used as a model system for studying other secreted proteins in yeast. Green fluorescent protein (GFP) from Aequorea victoria was fused to the carboxy-terminus of the enzyme by genomic integration to the locus ASP3 of $S$. cerevisiae. We determined asparaginase II activity, $\mathrm{mRNA}_{\mathrm{ASP}}, \mathrm{mRNA}_{\mathrm{ASP} 3-\mathrm{GFP}}$ and GFP fluorescence. Nitrogen starvation in cells carrying the chimera ASP3-GFP caused an increase in fluorescence and in the expression of ASP3. We have shown that cells producing the chimera Asp3-GFPp displayed the same response to nitrogen starvation as control cells. We demonstrated that Asp3-GFPp can be used for studying asparaginase II secretion under nitrogen starvation in vivo.
\end{abstract}

Key words: asparaginase II, nitrogen regulation, Saccharomyces cerevisiae, genomic integration, green fluorescent protein

\section{INTRODUCTION}

Saccharomyces cerevisiae provides an attractive system for genetically dissecting mechanisms that regulate trafficking of a secreted protein. Yeast produces periplasmic asparaginase II (asparaginase amidohydolase, E.C. 3.5.1.1) that is encoded by the $A S P 3$ and regulated by nitrogen starvation $(1,4,6)$. The regulation of yeast asparaginase II can be used as a model for studies of the regulatory system for other extracellular enzymes. The production of asparaginase II has been shown to be regulated by Ure2p and GATA factors, Gln3p, Nillp, and Dal80p $(1,6,8,9,12)$. Although previous studies indicated that activity levels in the periplasmic space are regulated by nitrogen, the details of this regulation remain poorly understood. The aim of the present work was to construct a chimera ASP3-GFP gene to produce an asparaginase II fused to the green fluorescent protein (GFP) from Aequorea Victoria to follow in vivo the dynamics of the secreted asparaginase II during nitrogen starvation.

\section{MATERIALS AND METHODS}

FY1679-28C (Mat $a$, ura3-52, leu 2- $\Delta 1$, trp $1-\Delta 63$, his3 $\Delta 200$, URE2, GAL2+) and P40-3C (Mat $\Delta$, ura3-52, leu2-3, ade2-102, ure $2 \Delta 11:: L E U 2)$ and their derivatives ASM-F3 and ASM-P2 were used as controls and ure 2 mutants, respectively. Primers shown in Table 1 (end1 - end2) and plasmid pFA6-GFP(S65T)kanMX6 were used to obtain the integrative cassette by PCR (13). The PCR reaction was carried out as outlined in (11) and the PCR product was used for yeast transformation. Transformants were selected using $200 \mathrm{mg} / \mathrm{L}$ of G418 as described in (5). Cells were cultivated in YPAD medium (2\% peptone, $2 \%$ glucose, $1 \%$ yeast extract and $0.01 \%$ adenine) and in minimal medium ( $2 \%$ glucose, $0.2 \%$ YNB w/o amino acid and ammonium sulphate, $0.9 \%$ ammonium sulphate or $0.2 \%$ proline (9). Cultures were incubated $\left(30^{\circ} \mathrm{C} / 160 \mathrm{rpm}\right)$, collected at exponential growth phase, and submitted or not to nitrogen starvation. Starving conditions and the assay for asparaginase

*Corresponding author: Mailing address: Instituto de Química, UFRJ - CT, Bloco A, Av. Brigadeiro Trompowsky s/n. Cidade Universitária, Ilha do Fundão. 21941-590, Rio de Janeiro, RJ, Brasil. E-mail: elba1996@iq.ufrj.br 
II activity followed methods described elsewhere $(1,8,12)$. Crude cell extracts were obtained as in (14). Protein determination was carried out as in (7). Cell samples for microscopic analysis of fluorescence were treated as described by (10). Cell extracts were obtained in crushing buffer with protease inhibitors (TrisHCl 20 mM pH 7.5; NaCl 0,1M; EDTA 0.1M; PMSF 1 mM; 0.01 $\mathrm{mg} / \mathrm{mL}$ pepstatin) as described by (14). Fluorescence of cell extracts was determined after sample incubation in ice for 10 min as described by (3). Equal amounts of protein from crude cell extracts were transferred to dried polyvinnylidene difluoride membrane with methanol to form a dot. The ASP3-GFP chimeric protein was detected using GFP-antibody (1:5,000 dilution) and WesternBreeze Cromogenic Kit-Anti Rabbit (Invitrogen). Southern and Northern blot analyses were performed according to standard techniques (11). Probes were prepared by PCR amplification of genomic DNA or pFA-GFPkanMX6 (using primers of Table 1), and blotting with ${ }^{32} \mathrm{P}$-labeled probes prepared with RediPrime II kit according to the manufacturer's instructions (Amersham Pharmacia Biotech).

\section{RESULTS AND DISCUSSION}

The chromosomal integration of GFP at the 3'-end of ASP3 ORF is shown schematically in Fig. 1. The presence of the fusion ASP3-GFP in the constructed strains (ASM-F3 and ASM-2P) was verified by PCR analysis using primer1, ADR1 or ADR2GFP, listed in Table 1 (data not shown). Southern blot analysis showed that two copies of ASP3 ORF were altered since they can be specifically detected by the probes ASP3 and GFP (Fig 4). The strains carrying the chimera ASP3-GFP gene were grown in YPAD to early stationary phase and submitted or not to nitrogen starvation for $2 \mathrm{~h}$. Fluorescence in ASM-F3 (URE2) cells was detected only after nitrogen starvation (Fig. 2-A/B). ASM-P2 (ure2) cells exhibited pre-starvation fluorescence, which increased with nitrogen starvation (Fig 2-E/F). ASP3GFP expression was also verified by Northern analysis (Fig. 5). The observed increase in both mRNA $_{\mathrm{ASP} 3}$ and $\mathrm{mRNA}_{\mathrm{ASP} 3-\mathrm{GFP}}$ corroborated results obtained fluorescence. The comparison of D-asparaginase II (DA-II) activity before and after nitrogen starvation in crude cell extract and periplasmic space of whole URE2 cells expressing either Asp3p or Asp3-GFPp also revealed an increase of DA-II activity due to nitrogen starvation in both wild-type and ure2 strains (Fig. 3). Determination of fluorescence in cell extracts before and after nitrogen starvation showed higher fluorescence for samples obtained from the chimera strains than for wild-type strains (Table 2). Further

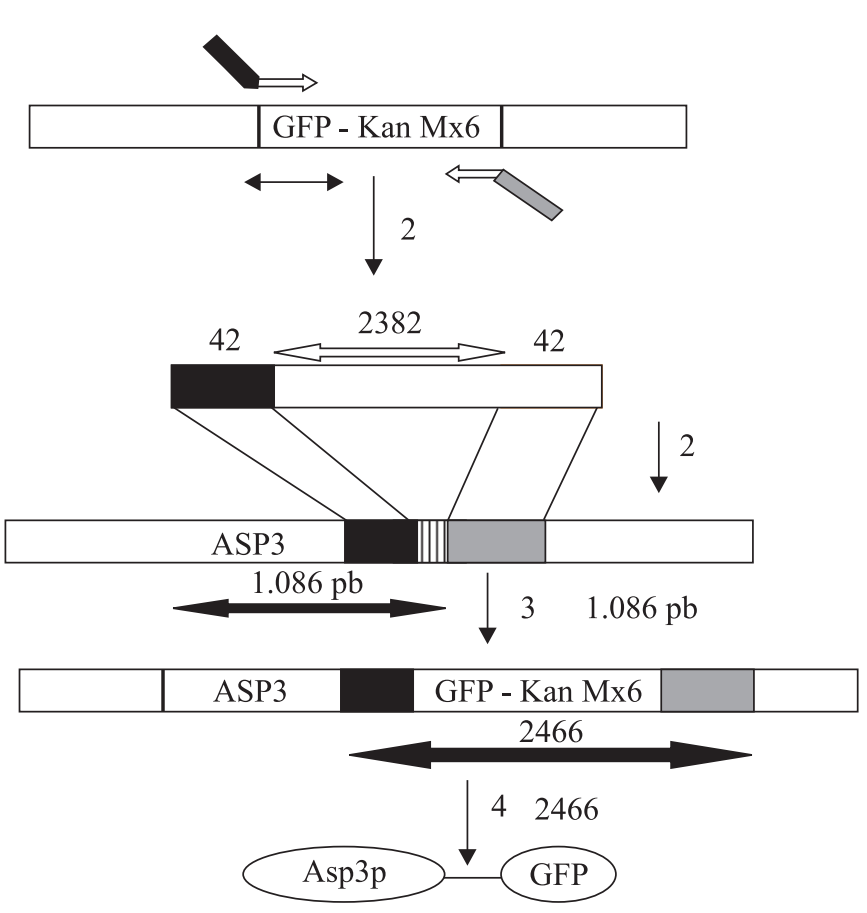

Figure 1. Scheme of the construction of ASP3-GFP fusion. (1) The PCR product was used to transform $w t$ and ure 2 strains (2) and integrated in the yeast genome by homologous recombination (3), resulting in the strains harboring the chimeric gene expressing the Asp3-GFP fusion protein (4) under the same regulatory control as Asp3p protein.

Table 1. Primers used in this study.

\begin{tabular}{ccc}
\hline Primer Number & Name & Sequence $\left(5^{\prime}-3^{\prime}\right)$ \\
1 & end 1 & $\begin{array}{r}\text { tacggcatggatcagattaggtctgtttttctggcgtctac } \\
\text { GTAAAGGAGAAGAACTTTC } \\
\text { tataaaacacactgtgatgaaagtcactgatcaggettt } \\
\text { ATGGATGGCGGCGTAGTATC }\end{array}$ \\
3 & end2 & TCGGATCCAGGGTAAACCCCGTCTCT \\
4 & Primer1 (372 nt upstream of ATG) & AGCAGCTGATCAGGCTTTAACCACCG \\
5 & ADR1 & GTGTGATGAAAAGCTACTGATCAGGC \\
\hline
\end{tabular}

Capital letters indicate sequence homologous to the respective template plasmids; small letters indicae sequence homologous to the respective chromosomal integration sites. 
A

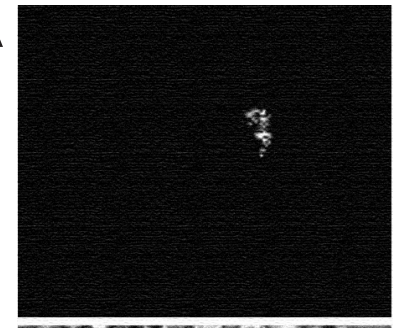

C

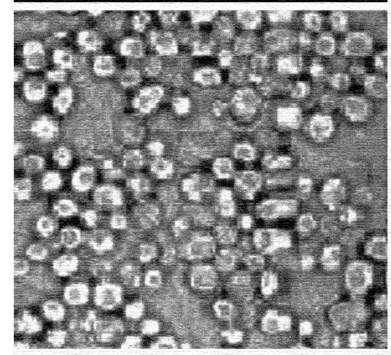

E
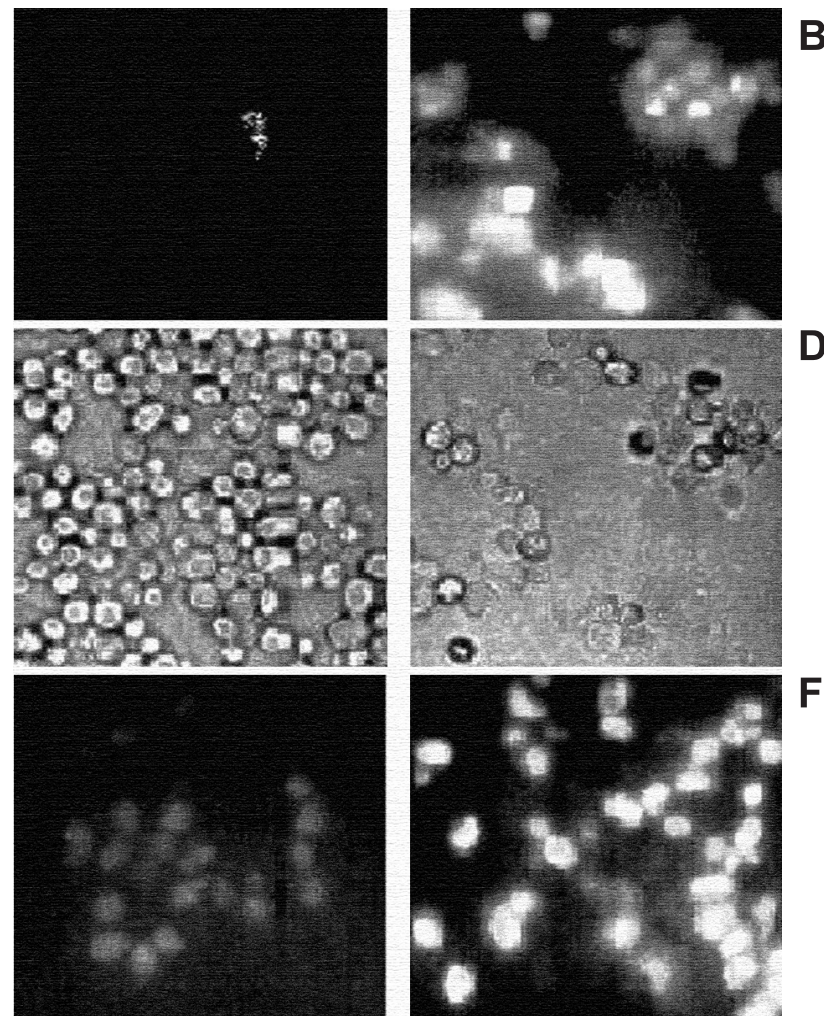

Figure 2. Microscopic inspection of cells harboring the chromossomal C-terminal Asp3-GFP fusion from cultures starved or not for nitrogen. (A and B) Fluorescence of ASM-F3 (URE2) cells from cultures non-starved and starved for nitrogen, respectively. (B and D) Optic microscopic images of ASM-F3 cells from cultures non-starved and starved for nitrogen, respectively.(E) Fluorescence of ASM-P2 (ure2) under non-starved condiction; (F) Fluorescence of ASM-P2 nitrogen starved $2 \mathrm{~h}$.
Table 2. Fluorescence measurements in cell extract.

\begin{tabular}{cccc}
\hline \multirow{2}{*}{ Cepas } & Genótipo Relevante & \multicolumn{2}{c}{$\begin{array}{c}\text { Fluorescência Relativa } \\
\text { após Depleção de } \\
\text { Nitrogênio }\end{array}$} \\
\cline { 3 - 4 } & & 0 min & 120 min \\
\hline FY1679-28C & URE2 ASP3 & 11 & 14 \\
ASM-F3 & URE2 ASP3-GFP & 24 & 78 \\
P40-3C & ure2 ASP3 & 13 & 13 \\
ASM-P2 & ure2 ASP3-GFP & 72 & 81 \\
\hline
\end{tabular}

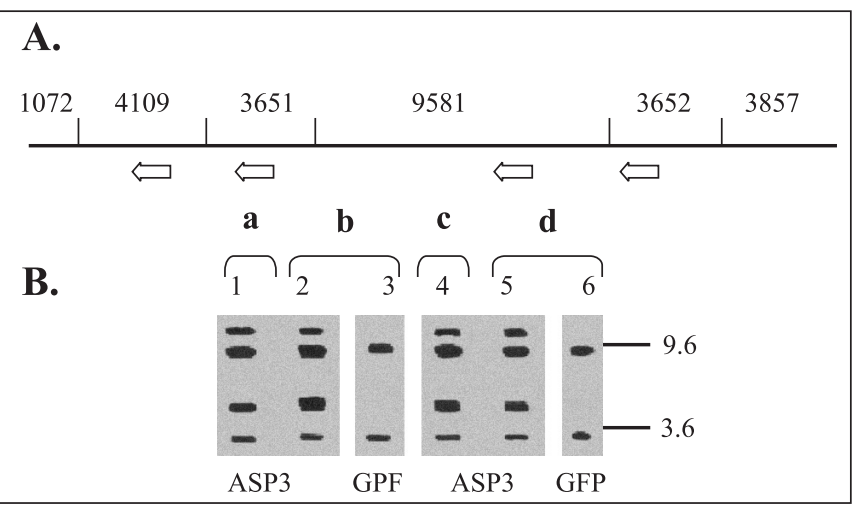

Figure 4. Southern hybridization analysis of yeast genomic DNA, after disruption of chromosome XII. (A) Map of the chromosome XII between coordinates $465977-491898$ bp. The location of the Hind III restriction sites is marked along the line that represents the DNA. The ASP3 ORFs and orientations are shown below. (B) X-ray film exposed to ASP3 probe (lanes: $1,2,4$ and 5) and to GFP probe (lanes 3 and 6) from total yeasts DNA of P40-3C (a), ASM-P2 (b), FY (c) and ASM-F3 (d).

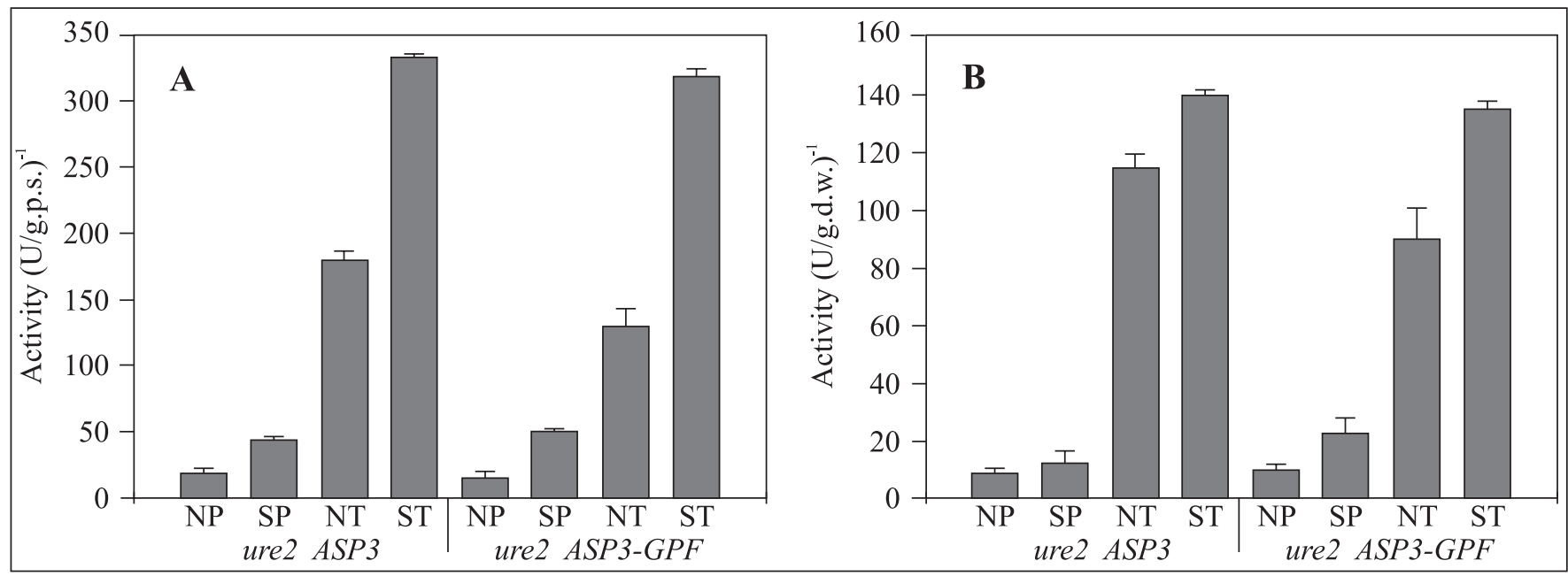

Figure 3. Asparaginase II activity measured in conditions of $(\mathrm{N})$ non-starved for nitrogen or $(\mathrm{S})$ starved for nitrogen and for $(\mathrm{P})$ periplasmic activity or $(\mathrm{T})$ total enzymatic activity in extract of the cells. 


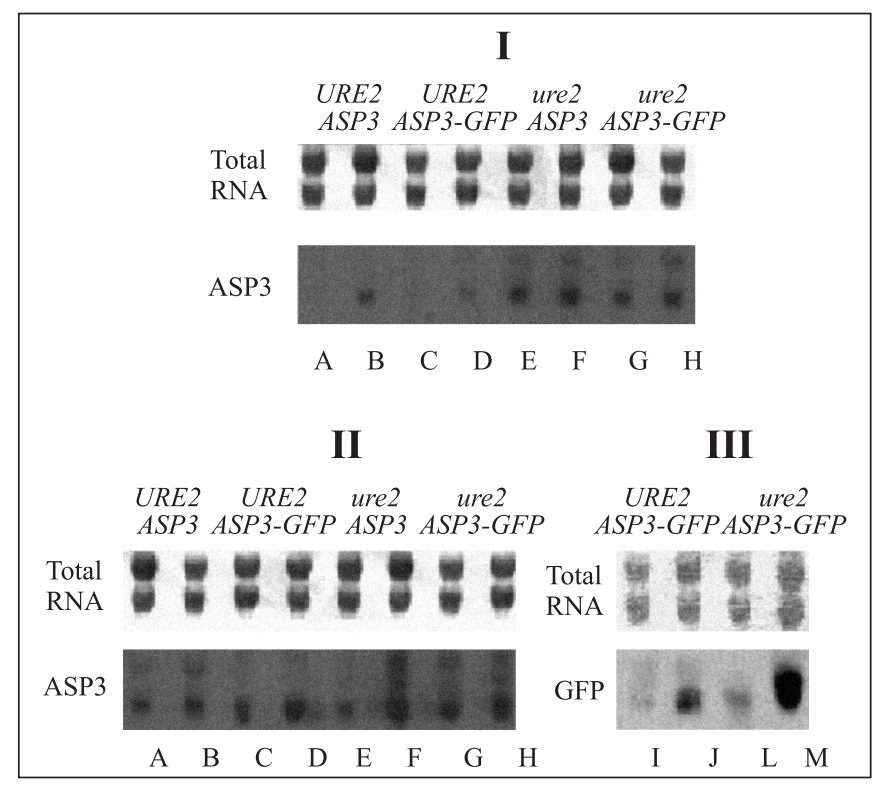

Figure 5. Northern blot of ASP3 steady-state mRNA levels in URE2 (FY1679-28C), URE2 ASP3-GFP (ASM-F3), ure2 ASP3 (P40-3C) strains. Cells were grown in $0.9 \%$ ammonium sulphate (I) and in $0.2 \%$ praline (II and III) media as the sole nitrogen source. $\mathrm{mRNA}_{\mathrm{ASP} 3}$ were analysed in fresh $(\mathrm{A}, \mathrm{C}, \mathrm{E}$ and $\mathrm{G})$ and nitrogen-starved cells $(\mathrm{B}, \mathrm{D}, \mathrm{F}$ and $\mathrm{H})$. $\mathrm{mRNA}_{\mathrm{ASP} 3 \text {-GFP }}$ were analysed in fresh ( $\mathrm{I}$ and $\mathrm{L}$ ) and nitrogen-starved cells ( $\mathrm{J}$ and $\mathrm{M}$ ). Total RNA is also shown for amount control.

demonstration of the ASP3-GFP protein was carried out using anti-GFP antibody. Cell extracts from strains expressing ASP3GFP protein exhibited a dot whose intensity was higher in samples obtained from nitrogen-starved cells (Fig. 6). These results indicate that both native ASP3 and modified copies are regulated by nitrogen and that specific sorting of Asp3p was not affected by the GFP fusion. Further research to verify the effect of nitrogen on asparaginase II secretion is currently ongoing.
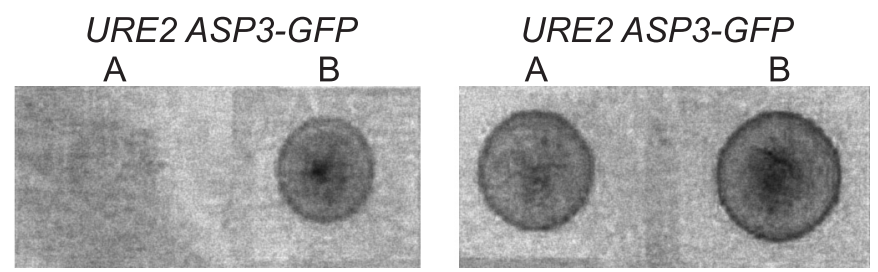

Figure 6. Western blot of Asp3-GFP protein levels in URE2 $A S P 3-G F P$ (ASM-F3) and ure 2 ASP3-GFP (ASM-P2) strains grown in YPD. Asp3-GFP protein levels were analyzed for extract of fresh (A) and for nitrogen-starved cells (B) after two hours under nitrogen starvation condition.

\section{ACKNOWLEDGEMENTS}

We are grateful to Maria Inez de Moura Sarquis (IOC/ FIOCRUZ) for use of fluorescent microscope facilities and to Professors Anna L. Okorokova-Façanha and Fernando Abad Franch, for reviewing the manuscript. Conselho Nacional de Pesquisa e Desenvolvimento (CNPq), FAPERJ, SR2-UERJ and FIOCRUZ-CPqL\&MD supported this work.

\section{RESUMO}

\section{Fusão asparaginase II-GFP como ferramenta para estudo da via secretora de enzima sobre depleção por nitrogênio}

A produção de asparaginase II de Saccharomyces cerevisiae é regulada por nitrogênio e pode ser utilizada como um sistema modelo para estudar outras proteínas secretadas, em leveduras. A proteína "green fluorescent protein" (GFP) de Aequorea victoria foi fusionada à porção carboxi-terminal de Asp3p por integração genômica da sequência de GFP ao locus ASP3. Determinaram-se os níveis de atividade de asparaginase II, $\mathrm{mRNA}_{\mathrm{ASP} 3}, \mathrm{mRNA}_{\mathrm{ASP} 3 \text {-GFP }} \mathrm{e}$ de fluorescência para GFP. A depleção para nitrogênio, em células portadoras do gene quimérico ASP3-GFP, fez aumentar a fluorescência, assim como a expressão de ASP3. Demonstramos que Asp3-GFPp pode ser utilizada para estudar a secreção de asparaginase II em células submetidas à privação de nitrogênio in vivo.

Palavras-chave: asparaginase II, regulação por nitrogênio, Saccharomyces cerevisiae, integração genômica, proteína de fluorescência verde.

\section{REFERENCES}

1. Bon, E.P.S.; Carvajal, E.; Stambrough, M.; Magasanik, B. Asparaginase II of Saccharomyces cerevisiae. GLN3/URE2 regulation of a periplasmic enzyme. Appl. Biochem. Biotecnol., 63-65, 203-212, 1997.

2. Coofman, J.A.; Cooper, T.G. Nitrogen GATA factors participate in transcriptional regulation of vacuolar protease genes in Saccharomyces cerevisiae. J. Bacteriol., 179(17):5609-5613, 1997.

3. Cubbit, A.B.; Heim, R.; Adams, S.R.; Boyd, A.E.; Gross, L.A.; Tsien, R.Y. Understanding, improving and using green fluorescent proteins. Trends Biol. Sci., 20:448-455, 1995.

4. Dunlop, P.C.; Even, H.L.; Roon, R.J. Utilization of D-asparagine by Saccharomyces cerevisiae. J. Bacteriol., 125(3):999-1004, 1976.

5. Guldener, U.; Heck, S.; Fiedler, T. A new efficient gene disruption cassete for repeated use in budding yeast. Nucleic acids Res., 24:25192524, 1996.

6. Kim, K.W.; Kamerud, J.Q.; Livingston, D.M.; Roon, R.J. Asparaginase II of Saccharomyces cerevisiae. Characterization of the ASP3 gene. J. Biol. Chem., 263(24):11948-11953, 1988.

7. Lowry, O.H.; Rosebrouch, N.J.; Farr, A.L.; Randall, R.J. J. Protein measurement with folin phenol reagent. J. Biol. Chem., 193:265275, 1951. 
8. Oliveira, E.M.M.; Carvajal, E.; Bon, E.P.S. L-asparaginase II of Activity Profile During na ure2 mutant P40-3C and P40-3C+URE2p strain. Appl. Biochem. Biotechnol., 77-79, 311-316, 1999.

9. Oliveira, E.M.M.; Sotero-Martins, A.; Carvajal, E.; Bon, E.P.S. The role of the GATA factors Gln3p, Nil1p, Dal80p and the Ure2p on ASP3 regulation in Saccharomyces cerevisiae. Yeast, 20(1):31-37, 2003.

10. Petersson, J.; Pattison, J.; Kruckeber, A.L.; Berden, J.A.; Persson, B.L. Intracellular localization of an active green fluorescent proteintagged Pho84 phosphate permease in Saccharomyces cerevisiae. FEBS Letters, 462:37-42, 1999.
11. Sambrook, J.; Frisch, E.F.; Maniatis, T. Molecular cloning - a laboratory manual, $2^{\text {nd }}$ edition. Laboratory Press, Cold Spring Harbor, NY, 1989.

12. Silveira, M.C.F.; Oliveira, E.M.M.; Carvajal, E.; Bon, E.P.S. Nitrogen Regulation of Saccharomyces cerevisiae Invertase: Role of the URE2 Gene. Appl. Biochem. Biotecnol., 84-86, 247-254, 2000.

13. Wach, A.; Brachat, A.; Aberti-Segui, C.; Rebischung, C.; Philippsen, P. PCR-Based Gene Targeting in Saccharomyces cerevisiae. Yeast, 13(11):1065-1075, 1997.

14. Walmsley, R.M.; Billinton, N.; Heyer, W.D. Green Fluorescent Protein as a Reporter for DNA Damage-induced Gene RAD54 in Saccharomyces cerevisiae. Yeast, 13:1535-1545, 1997. 